\title{
Iraqi Propolis, Carbimazole, Levothyroxine and their Propolis Combinations Effects on Renal Histopathological Parameters in Female Rats
}

\author{
Ghadeer Hamad Al-Seray ${ }^{1}$ \\ https://orcid.org/0000-0001-8810-5189
}

Asia Selman Abdullah ${ }^{1}$

https://orcid.org/0000-0002-7384-0313

\author{
Muhsin Sagheer AL-Mozie'I' \\ https://orcid.org/0000-0002-6789-7188 \\ ${ }^{1}$ University of Basrah, College of Pharmacy, Department of Pharmacology and Toxicology, Basrah, Iraq. \\ Editor-in-Chief: Alexandre Rasi Aoki \\ Associate Editor: Jane Manfron Budel
}

Received: 2021.04.07; Accepted: 2021.06.23.

*Correspondence: asiaselman2016@gmail.com; Tel.: +9647719532885 (A.S.A.).

\section{HIGHLIGHTS}

Propolis combinations with carbimazole or levothyroxine have an effect on blood in female rats.

Carbimazole dose of $0.01 \mathrm{mg} / \mathrm{g}$ for six weeks causes renal damage in female rats.

Levothyroxine dose of $0.1 \mu \mathrm{g} / \mathrm{g}$ for six weeks causes renal degenerative effects.

Iraqi PR dose of $50 \mathrm{mg} / \mathrm{kg}$ for six weeks have a renal protective effect.

Abstract: Iraqi propolis (PR) have powerful antioxidants, free radical scavenger and anti-inflammatory constituents makes it to have a protective effect on renal function. The aim of this study is to evaluate the possible protective effect of Iraqi propolis (PR) on renal toxicity induced by Carbimazole (CB) and levothyroxine (TR) in rats. Forty-two adult female albino rats randomized into six groups: control, PR, CB, $T R, P R+C B$ and $P R+T R$. Rats orally treated by gavage for six weeks. Haematological and histopathological analyses performed. A significant increase in hemoglobin percentage, RBC count and Haematocrit percentage after exposure to PR + CB and PR + TR combinations compared to control. CB dose of $0.01 \mathrm{mg}$ $\mathrm{lg}$ for six weeks causes renal damage in female rats and TR dose of $0.1 \mu \mathrm{g} / \mathrm{g}$ for six weeks causes renal degenerative effects. Rats treated with $\mathrm{PR}+\mathrm{TR}$ show normal appearance in kidney tissue, glomeruli and renal tubules compared to thyroxin group alone. In addition, $P R+C B$ treatment show more improvement in renal tissue, normal glomeruli and renal tubules compared to $C B$ alone. It is concluded that $\mathrm{PR}$ combination with CB or TR might have an effect on the blood, further studies needed to confirm this effect on human to be used for anemia accompanied thyroid disruptions. In addition, further studies needed to confirm renal protective effect on human to be used for this effect.

Keywords: Iraqi propolis; Carbimazole; Levothyroxine; Renal histopathology. 


\section{INTRODUCTION}

Thyroid hormones are a mainstay of the regulation of metabolism. Carbimazole (CB) and its metabolism product methimazole (MM), besides Polypropylthiouracil, are antithyroid drugs broadly used and they act by reduction of iodine incorporation into thyroglobulin for the production of thyroid hormones and reducing the synthesis and production of the thyroid hormones by thyroid gland. In spite of their therapeutic approaching, the clinical achievement of antithyroid drugs constricted by harmful effects such as nephrotoxicity, hepatotoxicity, acute pancreatitis, neurotoxicity, carcinoma of thyroid and testicular harmfulness [1,2].

Levothyroxine (TR) is an artificial thyroid hormone used for the management of hypothyroidism, when administered for hypothyroid cases, up-regulates TSH receptors causes increased $\mathrm{T}_{4}$ and $\mathrm{T}_{3}$ release [3]. In addition, TR increases serum protein level, exerts its effect through the control of DNA transcription and protein synthesis [4].

Propolis (PR) (bee glue) the resin honeycomb produce gathered via bees from diverse plants used to restore the honeycomb and make a defensive fence against invaders [5]. PR accepted as an alternative medicine to ameliorate health and prevent some diseases, it can be used to reduce glucose, cholesterol and blood pressure levels [6, 7] also to increase the natural body resistance against infections [8,]. PR can enhance hepatorenal function by decreasing liver and kidney oxidative stress [9-13]. However, the impact of PR is uncertain on hepatorenal function in diabetic rats [9]. Irinotecan nephrotoxic effect has been reported to be decreased by PR [14]. High antioxidant activity reflects the composition of PR [15] and thus may be examined for the treatment of renal ischemia-reperfusion damage [16]. Studies have indicated PR to act as a vigorous anti-inflammatory agent, part of the material present in PR can inhibit cyclooxygenase and the resulting prostaglandins synthesis [17]. PR constituents differs with the geographic region and through the seasons; such variability between samples from diverse sources causes a difference in the pharmacological effects of PR $[18,19]$. Different types of PR demonstrate various biological properties including antifungal, antibacterial, antiprotozoal, antitumor, antioxidant, anti-inflammatory, antiproliferative and anticariogenic activities, in addition to its immunomodulatory and wound healing effects [20]. Previously, the chemical constitution of Iraqi propolis studied quantitatively, its main constituents are polyphenolic compounds, like flavones, flavonones, terpenes, fatty acid, phenolic acid and esters. Furthermore, about 32 different flavonoids detected in Iraqi propolis extracts by the use of higher pressure liquids chromatography joined with electro sprayed mass spectrometry (HPLC-ESI-MS) [21]. Another study revealed that an antioxidant action of PR is four times greater than vitamin E, also $25-50$ folds greater effect than fruits [22]. These powerful antioxidants, free radical scavenger and anti-inflammatory constituents makes it to have a protective effect on renal function. The aim of this study is to evaluate the possible protective effect of Iraqi propolis (PR) on renal toxicity induced by Carbimazole (CB) and levothyroxine (TR) in rats.

\section{MATERIAL AND METHODS}

\section{Materials}

The Iraqi PR sample collected from Al-Tarmyia town (60 km northeast of Baghdad, Iraq) in different seasons by scraping it off from the frames of beehives and stored at $4^{\circ} \mathrm{C}$. Carbimazole $5 \mathrm{mg}$ film coated tablet obtained from Remedica Ltd.phaemaceutical Company in Limassol-cyprus- Europe. Levothyroxine tablet (Euthyrox $100 \mu \mathrm{g}$ ) obtained from Merk KGaA Research and product development in Darmstadt, Germany. Dimethyl sulfoxide obtained from Sigma Aldrich.

\section{Methods}

Forty- two adult Sprague Dawley female rats (from the drug control and scientific research department in Baghdad) (weighing 200-300 gram) were included in the study. The female rats were in the same stage of hormonal cycle to avoid bias, placed in plastic cages in pairs, in the normal conditions in the lab with regard to air, humidity; the temperature was $28 \pm 3^{\circ} \mathrm{C}$, with 12 hours light, and 12 hours dark cycle, provided water ad libitum. After adaptation period, rats were divided arbitrarily into six groups that seven rats in each. Group 1 , is a Control, received $0.5 \mathrm{~mL}$ of (distilled water with two drops of DMSO) once daily for six weeks. Group 2, PR group, received $0.5 \mathrm{~mL}$ of Iraqi PR $50 \mathrm{mg} / \mathrm{kg}$ body weight, dissolved in (distilled water with two drops of DMSO) once daily for six weeks. Group 3, CB group, received $0.5 \mathrm{~mL}$ of CB $0.01 \mathrm{mg} / \mathrm{g}$ body weight, 
dissolved in (distilled water with two drops of DMSO) once daily for six weeks. Group 4, TR group, received $0.5 \mathrm{~mL}$ of TR $0.1 \mu \mathrm{g} / \mathrm{g}$ body weight, dissolved in (distilled water with two drops of DMSO) once daily for six weeks. Group 5, PR + CB group, received $0.5 \mathrm{~mL}$ of PR $50 \mathrm{mg} / \mathrm{kg}$ and CB $0.01 \mathrm{mg} / \mathrm{g}$ dissolved in (distilled water with two drops of DMSO) once daily for six weeks. Group 6, PR + TR group, received $0.5 \mathrm{~mL}$ of PR 50 $\mathrm{mg} / \mathrm{kg}$ and CB $0.1 \mu \mathrm{g} / \mathrm{g}$ dissolved in (distilled water with two drops of DMSO) once daily for six weeks. The weight of rats measured at the beginning of the experiment and then measured every two weeks.

After six weeks period of treatments, the rats sacrificed and blood collected via vena cava from all animals at the end of experiment and blood kept in tube with anticoagulant. Hematological parameters done in the University of Basrah by using hematological autoanalyzer (Count 60) made in Genex Company. White and red blood cell counts, hemoglobin $(\mathrm{Hb})$ and hematocrit $(\mathrm{Ht})$ concentrations, mean corpuscular volume (MCV), mean corpuscular hemoglobin (MCH), platelet count (PLT), Lymphocyte count, neutrophil count, and MID (the combined value of the other types of white blood cells not classified as lymphocyte or granulocyte) also estimated. Kidneys were excised for histopathological examination.

Histopathological investigation was prepared by fixing the tissues in $10 \%$ formalin solution for 4 days, after that the tissues partitioned, and fixed in paraffin. The histological pieces cut at $4-5 \mu \mathrm{m}$ before staining using hematoxylin $(\mathrm{H})$ and eosin $(\mathrm{E})$ [23]. The stained sections examined by a histopathologist under a light dissecting microscope.

\section{Statistical analysis}

Statistical analyses performed by a software Graph Pad Prism (type 7.0, Graph Pad Software, Inc., San Diego, CA). Descriptive statistics data presented as mean \pm SD for all estimated parameters. Statistical evaluations among groups achieved with one-way analysis of variance (ANOVA), then Bonferroni's Multiple Comparison test. All $p$ values that were $<0.05$ were considered significantly different [24]

\section{RESULTS}

\section{Effect of different treatments on rat's hematological parameters:}

The results revealed that there is a significant increase in hemoglobin percentage and red blood cells count after exposure to PR + CB $(p<0.0001)$ and PR + TR $(p<0.05)$ combinations compared to control. Furthermore, there is a significant increase $(p<0.0001)$ in white blood count after exposure to $P R+C B$. In addition, there is a significant increase $(p<0.0001)$ in the percentage of rare cells (MID \%) in all treatments compared to control except PR treatment. Moreover, there is a significant increase $(p<0.0001)$ in the Hematocrit percentage after exposure to $\mathrm{PR}+\mathrm{CB}$ and $\mathrm{PR}+\mathrm{TR}$ combinations compared to control. Other groups show no significant changes in the hematological parameters (Table 1).

\section{Histopathological study of the kidneys tissue:}

The kidney tissue examination of the control group has shown the histological structure revealed glomeruli with thin glomerular basement membrane, cellularity and patent capsular space surrounding proximal and distal convoluted tubules (Figure 1). The kidney section from female rats treated with $50 \mathrm{mg} / \mathrm{kg}$ b.w. of PR, showed normal glomeruli with Bowman's space and cells lining renal tubules (Figure 2). Female rats treated with $0.01 \mathrm{mg} / \mathrm{g}$ b.w. CB led to more deleterious histological changes in kidney represented in massive hemorrhagic areas, in addition to infiltration of the inflammatory cells surrounding thickened blood vessels and necrosis in the epithelial cells lining glomeruli and renal tubules (Figure 3). Treatment with $0.1 \mu \mathrm{g} / \mathrm{g}$ b.w of TR result in obvious histological changes include renal tubules and glomeruli; epithelial cells lining renal tubule were degenerated and necrotized in addition to hemorrhage in the interstitial tissue and narrowing of the tubular lumen. Moreover presenting necrosis in the cells lining the glomerular capsule, and sloughing of tubular epithelial cells in the tubular lumen (Figure 4). Female rats treated with PR $+\mathrm{CB}$ notice more productive renal tissues, shows normal glomeruli and renal tubules compared with CB alone (Figure 5). On the other hand, kidney section of female rat treated with TR + PR revealed more productive, shows normal glomeruli and renal tubules compared with TR alone (Figure 6). 
Table 1. Comparison between different treatment groups in terms of hematological parameters.

\section{Variables} Groups ( $n=7$ in each group)

\begin{tabular}{lccclll} 
& $\mathrm{C}$ & $\mathrm{PR}$ & $\mathrm{CB}$ & $\mathrm{TR}$ & $\mathrm{PR}+\mathrm{CB}$ & $\mathrm{PR}+\mathrm{TR}$ \\
\hline $\mathrm{Hb}(\%)$ & $14.4 \pm 0.3$ & $15.5 \pm 0.3$ & $15.5 \pm 0.3$ & $14.3 \pm 0.5$ & $18.1 \pm 0.6^{\mathrm{a}}$ & $17.8 \pm 0.2^{\mathrm{b}}$ \\
$\mathrm{RBC}\left(\times 10^{12} / \mathrm{L}\right)$ & $5.3 \pm 0.1$ & $5.3 \pm 0.5$ & $5.1 \pm 0.5$ & $5.3 \pm 0.3$ & $6.5 \pm 0.1^{\mathrm{a}}$ & $6.6^{\mathrm{a}} \pm 0.3^{\mathrm{b}}$ \\
Haematocrit $(\%)$ & $33.6 \pm 1.4$ & $33.6 \pm 2.9$ & $32.3 \pm 2.8$ & $32.1 \pm 0.7$ & $42.3 \pm 1.1^{\mathrm{a}}$ & $40.8 \pm 1.0^{\mathrm{a}}$ \\
Platelets $\left(\times 10^{9} / \mathrm{L}\right)$ & $254.7 \pm 56$ & $173.3 \pm 26$ & $261.3 \pm 63$ & $260.0 \pm 30$ & $219.0 \pm 39$ & $191 \pm 47$ \\
$\mathrm{MCV}(\mathrm{FL})$ & $63.4 \pm 1.0$ & $63.9 \pm 0.8$ & $62.4 \pm 0.9$ & $62.0 \pm 1.0$ & $64.8 \pm 1.8$ & $65.6 \pm 2.5$ \\
$\mathrm{MCH}(\mathrm{pg})$. & $27.7 \pm 0.6$ & $27.1 \pm 1.2$ & $26.7 \pm 1.4$ & $27.1 \pm 1.0$ & $28.5 \pm 1.3$ & $29.0 \pm 1.1$ \\
$\mathrm{WBC}\left(\times 10^{9} / \mathrm{L}\right)$ & $5.2 \pm 1.0$ & $6.9 \pm 0.6$ & $6.7 \pm 1.2$ & $6.2 \pm 0.9$ & $8.4 \pm 1.3^{\mathrm{a}}$ & $6.5 \pm 0.6$ \\
Lymphocyte $\left(\times 10^{9} / \mathrm{L}\right)$ & $3.6 \pm 0.7$ & $4.5 \pm 0.8$ & $4.1 \pm 0.9$ & $3.7 \pm 0.7$ & $4.6 \pm 0.6$ & $4.4 \pm 0.8$ \\
Granulocytes $\left(\times 10^{9} / \mathrm{L}\right)$ & $1.2 \pm 0.2$ & $1.2 \pm 0.2$ & $1.6 \pm 0.4$ & $1.3 \pm 0.3$ & $1.6 \pm 0.3$ & $1.6 \pm 0.4$ \\
MID $(\%)$ & $0.6 \pm 0.2$ & $0.7 \pm 0.2$ & $1.1 \pm 0.2^{\mathrm{a}}$ & $1.4 \pm 0.2^{\mathrm{a}}$ & $1.1 \pm 0.2^{\mathrm{a}}$ & $1.3 \pm 0.1^{\mathrm{a}}$
\end{tabular}

Data are presented as mean \pm standard deviation, ${ }^{\mathrm{a}} \mathrm{P}<0.005$ and ${ }^{\mathrm{b}} \mathrm{P}<0.05$ compared with control. 


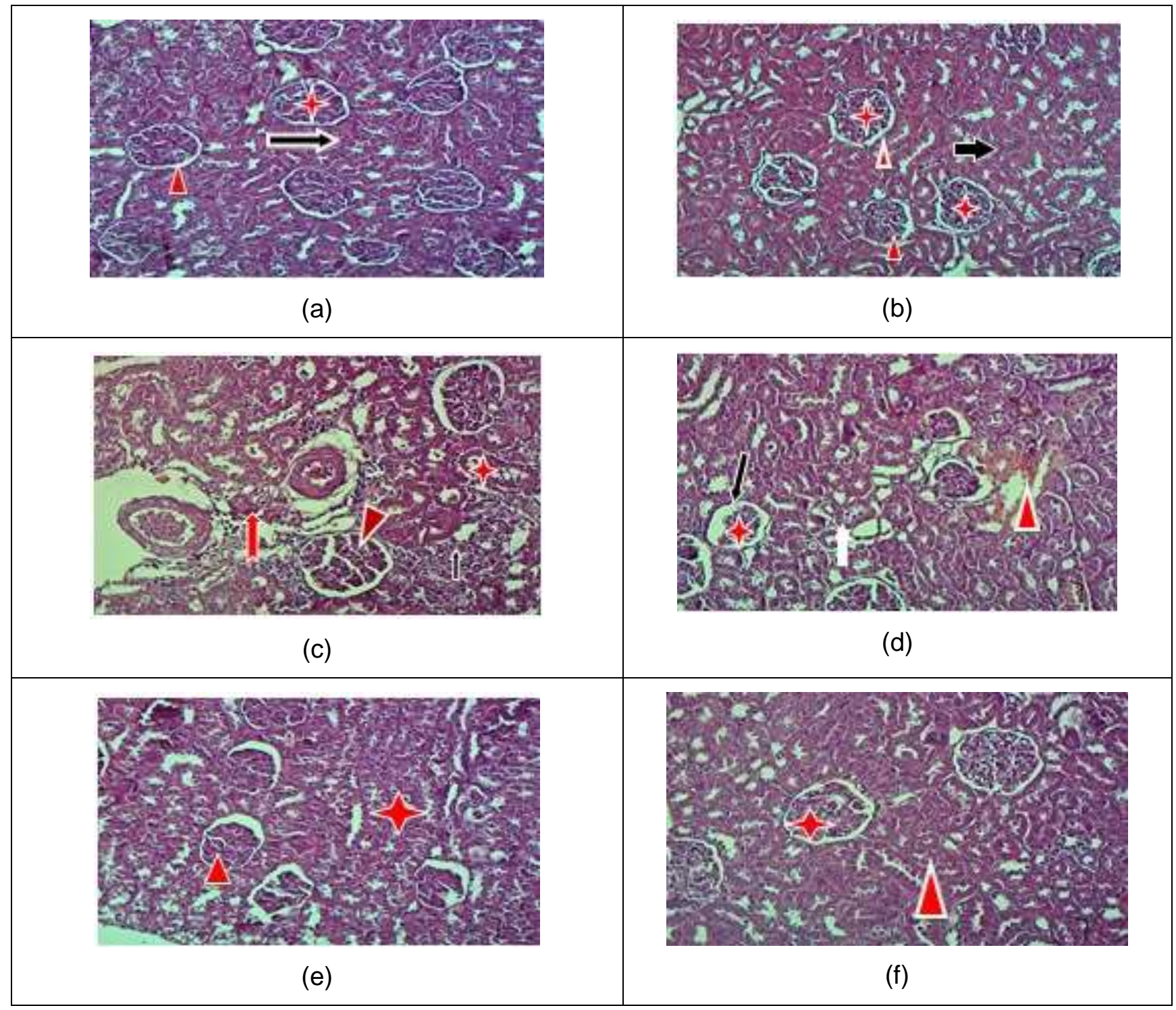

Figure 1. Light micrograph for kidney (stained with $\mathrm{H}$ and $\mathrm{C}$ ) 20X. (a) Control female rat, shows normal renal glomeruli (star) with normal Bowman's space (head arrow) and tubules (thick arrow). (b) Propolis (PR) $(50 \mathrm{mg} / \mathrm{kg})$ normal renal glomeruli (stars) with normal Bowman's space (head arrow) and tubules (thick arrow). (c) Carbimazole (CB) $(0.01 \mathrm{mg} / \mathrm{g})$ shows necrosis in the luminal epithelia (black arrow) with glomeruli, hemorrhagic area between renal tubule (head arrow) and precipitation of cellular substances in tubular lumen (starts), and dilatation of renal tubules (red arrow). (d) Thyroxin (TR) $(0.1 \mu \mathrm{g} / \mathrm{g}$ ) shows necrosis in the luminal epithelia (white arrow), hemorrhagic area between renal tubule (head arrow) and precipitation of a cellular substances in tubular lumen (start), atrophy in the glomerular capillary tuff dilatation of Bowman's space (black arrow). (e) PR + CB treatment shows additional productive renal tissue, normal glomeruli (head arrow) and renal tubules (star). (f) PR + TR treatment shows normal kidney tissue, glomeruli (star) and renal tubules (head arrow).

\section{DISCUSSION}

Studies indicated that PR have a powerful antioxidants and anti-inflammatory constituents makes it as a candidate to study its effect on renal function. This study aimed to investigate and compare the effect of Iraqi PR supplementation, Carbimazole (CB), levothyroxine (TR) and their PR combinations on the normal renal function

This study revealed that there is a significant increase in hemoglobin percentage; RBC count and Hematocrit percentage after exposure to PR + CB and PR + TR combinations compared to control. These results indicated that $\mathrm{PR}$ combination with $\mathrm{CB}$ or TR might have an effect on the blood, needs further studies to confirm.

Concerning the effects of different treatments on kidneys, the kidney histopathological finding indicated that PR restored kidney disrupted by TR and CB, confirmed that Iraqi PR have renal protective effect. The 
effect of CB and TR on kidney are consistent with previous study [25]. However, the duration of treatment of that study are different it was 30 days period. The results of CB and TR alone effects on kidneys are not in cope with a previous study that investigated the effects of $\mathrm{CB}$ and TR alone or in combination with gentamycin on renal biochemical and histopathological parameters. They concluded that administration of $12 \mathrm{mg} / \mathrm{ml} / \mathrm{day}$ CB to rats with drinking water for 21 days produces only mild tubular necrosis. Furthermore, that study revealed the S.C. administration of $0.1 \mu \mathrm{g} / \mathrm{g} /$ day TR to rats for 21 days have no effects on renal function [26]. This variation related to the difference of dose and duration of treatments. Another study find that PR have renal protective effect by the use of rat model with chronic kidney disease and hypertension, the study found that PR reduces arterial pressure, glomerulosclerosis, proteinuria, and the inflammation in renal tissue, in addition to reduction in oxidative stress [27].

Rats treated with PR+TR show normal appearance in kidney tissue, glomeruli and renal tubules in compare with thyroxin group alone. In addition, $\mathrm{PR}+\mathrm{CB}$ treatment show more protective renal tissue, normal glomeruli and renal tubules compared to kidney of $C B$ group which show necrosis in the luminal epithelia with glomeruli, hemorrhagic area between renal tubule, precipitations of cellular substances in tubular lumen and dilation of renal tubules.

To the best of our knowledge, this is a first study about the comparisons and combinations of PR with CB or TR effects on renal system.

\section{CONCLUSION}

In conclusion, there is a significant increase in hemoglobin percentage; RBC count and Hematocrit percentage after exposure to $\mathrm{PR}+\mathrm{CB}$ and $\mathrm{PR}+\mathrm{TR}$ combinations compared to control. These results indicated that PR combination with CB or TR might have an effect on the blood, further studies needed to confirm this effect on human to be used for anemia accompanied thyroid disruptions.

Kidney histopathological finding indicated that PR restored kidney disrupted by TR and CB, confirmed that Iraqi PR have a renal protective effect. Further studies needed to confirm this effect on human to be used for renal protection.

Funding: This research received no external funding.

Acknowledgments: This study is a part from M.Sc. thesis submitted to the College of Pharmacy, Department of Pharmacology and Toxicology, University of Basrah. The authors thank the college for encouragement and continuous support.

Conflicts of Interest: The authors declare no conflict of interest.

\section{REFERENCES}

1. Vilchez FJ, Torres I, Garcia-Valero A, López-Tinoco C, los Santos AD, Aguilar-Diosdado M. Concomitant agranulocytosis and hepatotoxicity after treatment with carbimazole. Annals of Pharmacotherapy. 2006 Nov; 40(11):2059-63.

2. Calañas-Continente A, Espinosa M, Manzano-García G, Santamaría R, Lopez-Rubio F, Aljama P. Necrotizing glomerulonephritis and pulmonary hemorrhage associated with carbimazole therapy. Thyroid. 2005 Mar 1;15(3):286-8.

3. Vaidya B, Pearce SH. Management of hypothyroidism in adults. Bmj. 2008 Jul 28;337.

4. Laurberg P. Mechanisms governing the relative proportions of thyroxine and 3,5, 3'-triiodothyronine in thyroid secretion. Metabolism. 1984 Apr 1;33(4):379-92.

5. Nguyen HX, Nguyen MT, Nguyen NT, Awale S. Chemical constituents of propolis from Vietnamese Trigona minor and their antiausterity activity against the PANC-1 human pancreatic cancer cell line. J. Nat. Prod. 2017 Aug 25;80(8):2345-52.

6. Zakerkish M, Jenabi M, Zaeemzadeh N, Hemmati AA, Neisi N. The effect of Iranian propolis on glucose metabolism, lipid profile, insulin resistance, renal function and inflammatory biomarkers in patients with type 2 diabetes mellitus: A randomized double-blind clinical trial. Scientific reports. 2019 May 13;9(1):1-1.

7. Zhou H, Wang H, Shi N, Wu F. Potential Protective Effects of the Water-Soluble Chinese Propolis on Hypertension Induced by High-Salt Intake. Clinical and translational science. 2020 Sep;13(5):907-15.

8. Teixeira EW. D. Message, G. Negri, A. Salatino, and P. C. Stringheta,"Seasonal variation, chemical composition and antioxidant activity of brazilian propolis samples,". Evidence-Based Complementary and Alternative Medicine. 2010;7(3):307-15.

9. Zhu W, Li YH, Chen ML, Hu FL. Protective effects of Chinese and Brazilian propolis treatment against hepatorenal lesion in diabetic rats. Human \& experimental toxicology. 2011 Sep;30(9):1246-55. 
10. Nirala SK, Bhadauria M. Propolis reverses acetaminophen induced acute hepatorenal alterations: a biochemical and histopathological approach. Archives of Pharmacal Research. 2008 Apr;31(4):451-61.

11. Kismet K, Sabuncuoglu MZ, Kilicoglu SS, Kilicoglu B, Devrim E, Erel S, Sunay AE, Erdemli E, Durak I, Akkus MA. Effect of propolis on oxidative stress and histomorphology of liver tissue in experimental obstructive jaundice. European Surgical Research. 2008;41(2):231-7.

12. Oktem F, Ozguner F, Sulak O, Olgar Ş, Akturk O, Yilmaz HR, Altuntas I. Lithium-induced renal toxicity in rats: protection by a novel antioxidant caffeic acid phenethyl ester. Molecular and Cellular Biochemistry. 2005 Sep;277(1):109-15.

13. Soleimani D, Rezaie M, Rajabzadeh F, Gholizadeh Navashenaq J, Abbaspour M, Miryan M, Razmpour F, Ranjbar G, Rezvani R, Jarahi L, Hashemy SI. Protective effects of propolis on hepatic steatosis and fibrosis among patients with nonalcoholic fatty liver disease (NAFLD) evaluated by real-time two-dimensional shear wave elastography: A randomized clinical trial. Phytotherapy Research. 2021 Mar;35(3):1669-79.

14. Ulusoy HB, Öztürk İ, Sönmez MF. Protective effect of propolis on methotrexate-induced kidney injury in the rat. Renal failure. 2016 May 27;38(5):744-50.

15. Patel S. Emerging adjuvant therapy for cancer: propolis and its constituents. Journal of dietary supplements. 2016 May 3;13(3):245-68.

16. Geyikoglu F, Koc K, Colak S, Erol HS, Cerig S, Yardimci BK, Cakmak O, Dortbudak MB, Eser G, Aysin F, Ozek NS. Propolis and its combination with boric acid protect against ischemia/reperfusion-induced acute kidney injury by inhibiting oxidative stress, inflammation, DNA damage, and apoptosis in rats. Biological trace element research. 2019 Dec;192(2):214-21.

17. Araujo MA, Libério SA, Guerra RN, Ribeiro MN, Nascimento FR. Mechanisms of action underlying the antiinflammatory and immunomodulatory effects of propolis: a brief review. Revista Brasileira de Farmacognosia. 2012 Feb;22(1):208-19.

18. Marcucci MC. Propolis: chemical composition, biological properties and therapeutic activity. Apidologie. 1995;26(2):83-99.

19. Greenaway W, Scaysbrook T, Whatley FR. The analysis of bud exudate of Populus $x$ euramericana, and of propolis, by gas chromatography-mass spectrometry. Proceedings of the Royal society of London. Series B. Biological sciences. 1987 Dec 22;232(1268):249-72.

20. Paulino N, Dantas AP, Bankova V, Longhi DT, Scremin A, de Castro SL, Calixto JB. Bulgarian propolis induces analgesic and anti-inflammatory effects in mice and inhibits in vitro contraction of airway smooth muscle. J. Pharmacol. Sci. 2003;93(3):307-13.

21. Sulaiman GM, Al Sammarrae KW, Ad'hiah AH, Zucchetti M, Frapolli R, Bello E, Erba E, D'Incalci M, Bagnati R. Chemical characterization of Iraqi propolis samples and assessing their antioxidant potentials. Food Chem. Toxicol. 2011 Sep 1;49(9):2415-21.

22. Kukner A, Colakoglu N, Ozogul C, Naziroglu M, Firat T. The effects of combined vitamin C and E in streptozotocininduced diabetic rat kidney. Clinical Reviews and Opinions. 2009 Nov 30;1(2):029-36.

23. Ali IH, Jabir MS, Al-Shmgani HS, Sulaiman GM, Sadoon AH. Pathological And immunological study on infection with escherichia coli in ale balb/c mice. InJournal of Physics: Conference Series 2018 May 1 (Vol. 1003, No. 1, p. 012009). IOP Publishing.

24. Kareem SH, Naji AM, Taqi ZJ, Jabir MS. Polyvinylpyrrolidone Loaded-MnZnFe 2 O 4 Magnetic Nanocomposites Induce Apoptosis in Cancer Cells Through Mitochondrial Damage and P 53 Pathway. J. Inorg Organomet Polym Mater. 2020 Dec;30(12):5009-23.

25. Al-Naely A, Shattnan D. Effect of grape seed extract on biochemical factor and histological changes in liver and the kidney in albino rat infected hypo-hyperthyroidism induced laboratory by carbimazole and I-thyroxine. J. Glob. Pharma Technol. 2017 Oct 10;9(9):174-81.

26. Ali BH, Bashir AA, Tanira MO. The effect of thyroxine or carbimazole treatment on gentamicin nephrotoxicity in rats. Hum Exp Toxicol. 1995 Jan;14(1):13-7.

27. Teles F, da Silva TM, da Cruz Júnior FP, Honorato VH, de Oliveira Costa H, Barbosa AP, et al.. Brazilian red propolis attenuates hypertension and renal damage in 5/6 renal ablation model. PLoS One. 2015 Jan 21;10(1):e0116535.

(C) 2021 by the authors. Submitted for possible open access publication under the terms and conditions of the Creative Commons Attribution (CC BY NC) license (https://creativecommons.org/licenses/by-nc/4.0/). 